\title{
Bibliometrics of Nicaraguan publications in the Science Citation Index Expanded
}

\author{
Julián Monge-Nájera ${ }^{1} \&$ Yuh-Shan $\mathrm{Ho}^{2 *}$ \\ 1. Laboratorio de Ecología Urbana, Vicerrectoría de Investigación, Universidad Estatal a Distancia, 2050 San José, Costa \\ Rica; julianmonge@gmail.com \\ 2. Trend Research Centre, Asia University, Taichung 41354, Taiwan; ysho@asia.edu.tw \\ * Correspondence
}

Received 26-IV-2016. C Corrected 20-X-2016. Accepted 22-XI-2016.

\begin{abstract}
Nicaragua is a small country in Central America and little has been published about its scientific output. Most of its publications available in international databases are about medicine and are produced by Universidad Nacional Autónoma de Nicaragua (Managua) as part of international collaborative teams. In this article we analyzed in more depth, and for a longer period than any previous study, the presence of Nicaraguan publications in the Science Citation Index Expanded until January, 2016. In total, 837 Nicaraguan articles were published in 456 journals (the top journal is the American Journal of Tropical Medicine and Hygiene). Internationally collaborative articles with 94 countries accounted for $92 \%$ of articles, while only $8.5 \%$ were exclusively Nicaraguan. The most cited article described the use of ketoconazole to treat Leishmaniasis. The authors with more publications in the database were A. Balmaseda, R. Peña, W. Strauch, and F. Bucardo. The top cited, exclusively Nicaraguan articles dealt with health problems, forest tenure, and food production. The article citation lifespan is surprisingly long: over 70 years. Most citations start seven years after publication and are not recorded by the Science Citation Index, which for that reason cannot be considered valid to evaluate the impact of Nicaraguan research. The predominance of English publications may reflect a bias of the database itself. Probably most of the scientific production of Nicaraguan scientists is published in Spanish, in many regional journals not included in the SCI-EXPANDED. Nicaraguan research centers lack appropriate infrastructure, staffing and financial resources: future achievements for Nicaraguan science should include a fair presence of female researchers, peer-to-peer level participation in international teams, and less dominance of health technologies. Rev. Biol. Trop. 65 (2): 643-655. Epub 2017 June 01.
\end{abstract}

Key words: Nicaragua, SCI-EXPANDED, Web of Science, research trend.

Nicaragua is a small Central American country located between Honduras and Costa Rica; before Internet, local researchers suffered from some degree of "scientific invisibility" (i.e. their publications were less likely to be found and cited by the scientific community). In recent years, regional databases such as RedALyC and Latindex have given Nicaraguan authors a greater visibility (Miguel, 2011). In its infancy, RedALyC covered only one journal from Nicaragua, versus eight from Costa Rica and none from Honduras (Aguado \& Rogel, 2006). RedALyC's large South American equivalent, SCIELO, covers 11 journals from Nicaragua and the same number from Honduras, but again these numbers are much lower than the 199 Costa Rican journals in the database (Flores, Penkoba, \& Román, 2009).

Unfortunately, no database is even close to being comprehensive for Latin American journals. Considering SCOPUS (Netherlands), RedALyC (Mexico) and SciELO (Brazil), Miguel (2011) found that the three must be taken simultaneously into account for a more representative panorama of Latin American research output. These three databases, the most important in the region, are dominated by large countries such as Brazil, Mexico, 
and Colombia; from Central America only Costa Rica has a significant presence because of its relatively large output (Miguel, 2011).

Considering number of publications and investment, the most efficient countries in Latin America are Argentina (2.89 publications for every million dollars invested in research), Chile (2.25) and Brazil (2.0). There are no data for Nicaragua, but its scientific apparatus is similar to that of Guatemala which has a high rate of 5.87 publications, possibly thanks to its participation in international medical projects (Gantman, 2008). In other words, countries with poorly developed science erroneously appear among the efficient countries because their authors exchange samples for coauthorships (Gantman, 2008). Like everywhere else in Latin America, most "visible" articles from Nicaragua originate in state institutions located in cities, not in rural settings, or in private universities (Ríos \& Herrero, 2005; Aguillo, Ortega, Prieto, \& Granadino, 2007).

A more recent scientometrics approach to evaluating scientific production in Nicaragua and other countries is the quantification of academic documents published on websites. In Latin America, website documents are produced in largest numbers by the three largest countries: Brazil, Mexico and Argentina (Aguillo et al., 2007). Unfortunately, Nicaragua has such a small output of scientific website documents that it does not appear at all among top 500 countries in web presence (in Central America only Costa Rica appears in that group according to Aguillo et al., 2007).

Nicaragua has been included in few studies about regional productivity, mainly regarding medical research. Statistics on biomedical articles in the 1980's found that Latin America was dominated by Brazil, Argentina and Mexico. From Central America, the leading country was Costa Rica with 160 articles in international databases, followed by Panama with 96 and Guatemala with 71. Nicaragua was in the lower group with only 49 documents, but it fares better if population size is taken into account; the per capita production indicates that the most productive countries in Central
America were, in descending order, Costa Rica, Panama and Nicaragua (Cañedo, Hernández, \& Fresno, 2003).

Considering health articles in the PubMed database, Nicaragua is near the bottom of the list: the Latin American leaders are Brazil, Mexico and Argentina, which together represent $82 \%$ of all articles. In Central America the leading countries are Costa Rica $(0.55 \%)$, Panama (0.21) and Guatemala (0.12). Nicaragua is in the lower group with a fraction of the production of its Central American neighbors, with $0.06 \%$ (Cañedo, 2009).

A general result of scientometric analyses in Latin America is that the countries with less scientific output have the highest levels of publications done under international collaboration. For example, collaboration rates in countries with large academic institutions (like Argentina, Brazil and Mexico) range from 42 to $34 \%$, while $90 \%$ of Nicaraguan research included in SCOPUS was produced under international collaboration (Santa \& Herrero, 2010).

Despite its small presence in other areas, Nicaragua fares better in studies about access to health services, by publishing $1.4 \%$ of all papers from Latin America, close to Costa Rica $(1.6 \%)$ and much higher than its other neighbor, Honduras (0.2\%; Raiher, 2010).

Most information about Nicaragua only includes the country as part of regional analyses, but there are two studies that deal exclusively with it. The first, by Picado, Munguía and Rojas (2010) found that the SCI-EXPANDED included 216 articles in 150 journals, dealing mostly with medicine (30\%), agriculture and biology (16\%), and environmental science (12\%). The most productive institution was the Universidad Nacional Autónoma de Nicaragua in León, with $25 \%$ of all publications. The second study, by Arencibia et al. (2011) reported that there were 529 Nicaraguan publications in the SCIMAGO database, $48 \%$ from public universities, dominated again by the Universidad Nacional Autónoma de Nicaragua in León, but followed by Universidad Agraria, 
Universidad Centroamericana, and Universidad Nacional de Ingeniería.

In this article, we analyze in more depth, and for a longer period, the presence of Nicaraguan publications in the Science Citation Index Expanded, focusing on institutions, authors, temporal trends and citation.

\section{MATERIALS AND METHODS}

We used the Science Citation Index Expanded (SCI-EXPANDED), Web of Science Core Collection, Thomson Reuters. We searched for documents with the word "Nicaragua" in the address field and found 786903 , published between 1900 and 2014 (Date of search: January $\left.16^{\text {th }}, 2016\right)$. In total, 1107 met our criteria (see below). Document information included names of authors, title, year of publication, journal, contact address, and yearly citation. We downloaded the data to Microsoft Excel and manually coded for country, institute and journal impact factors. Errors in the data were reviewed by hand by a person familiar with the Nicaraguan research institutions (JMN). We obtained each journal's impact factor from the $2014 \mathrm{JCR}\left(I F_{2014}\right)$ and article Web of Science Core Collection citations from publication to the end of $2014\left(T C_{2014}\right.$; Wang, Yu, \& Ho, 2010). We also used $C_{2014}$, the total number of citations of a paper in 2014 only (Ho, 2012) and citations per total publications $(T P)$ since publication $\left(C P P=T C_{2014} / T P\right)$.

We reclassified articles from England, Scotland, Northern Ireland, and Wales as "United Kingdom" (UK); Zaire as "Democratic Republic of Congo", and some USSR as "Ukraine" after checking details. Here we compared Nicaraguan results with Honduras (similar in size and population) and Costa Rica (a smaller country) because these two countries are the closest neighbors of Nicaragua and are culturally similar.

A potential bias in the analysis of institutions might occur when authors used different affiliation spelling for the same institution (Fu, Long, \& Ho, 2014). We checked for this problem by hand and found up to 15 spellings for the same Nicaraguan institution, so we merged the data under a single, official name, for example, "Hosp Infantil Manuel Jesus Rivera" and "Hosp Infantil Manuel de Jesus Rivera" were merged as "Hospital Infantil Manuel de Jesús Rivera”.

The top 10 institutions were ranked by the following factors: total number of articles (including the institutional independent articles, nationally collaborative articles, and internationally collaborative articles), first author articles, and corresponding author articles.

\section{RESULTS}

Document Type and Language of Publication: There were 13 document types in the Science Citation Index Expanded from 1900 to 2014 (Fig. 1). The maximal $C P P$ value was in book chapters $(C P P=35)$ but only two were published: the most cited was "Decentralization of natural resource governance regimes" published in 2008 by A. Larson from the Center for International Forestry Research in Nicaragua and $\mathrm{A}$. Soto from the University of Texas (USA), with a $T C_{2014}$ of 65 . Most of the documents were articles (837 articles; $76 \%$ of 1107 publications), followed by meeting abstracts (129; $12 \%)$, letters $(75 ; 6.8 \%)$, proceedings papers $(26 ; 2.3 \%)$, reviews $(21 ; 1.9 \%)$, and editorial materials $(20 ; 1.8 \%)$. We extracted 837 articles for further analyses: $95 \%$ were in English (793 articles), followed by Spanish (29; $3.5 \%)$, French (10; $1.2 \%)$, Portuguese (3; $0.35 \%)$, and German ( $2 ; 0.24 \%)$.

Web of Science Categories and Journals: According to Journal Citation Reports (JCR) of 2014, it indexes 8659 journals across 176 SCI-EXPANDED categories, and Nicaraguan research appeared in 116 of those categories (Fig. 2 shows the top 12 categories that published at least 30 articles). The top categories with at least 70 articles were Public, environmental and occupational health (124 articles; $15 \%$ of 837 articles), Tropical medicine $(76 ; 9.1 \%)$, Infectious diseases $(73 ; 8.7$ $\%)$, and Environmental sciences (70; $8.4 \%)$. 


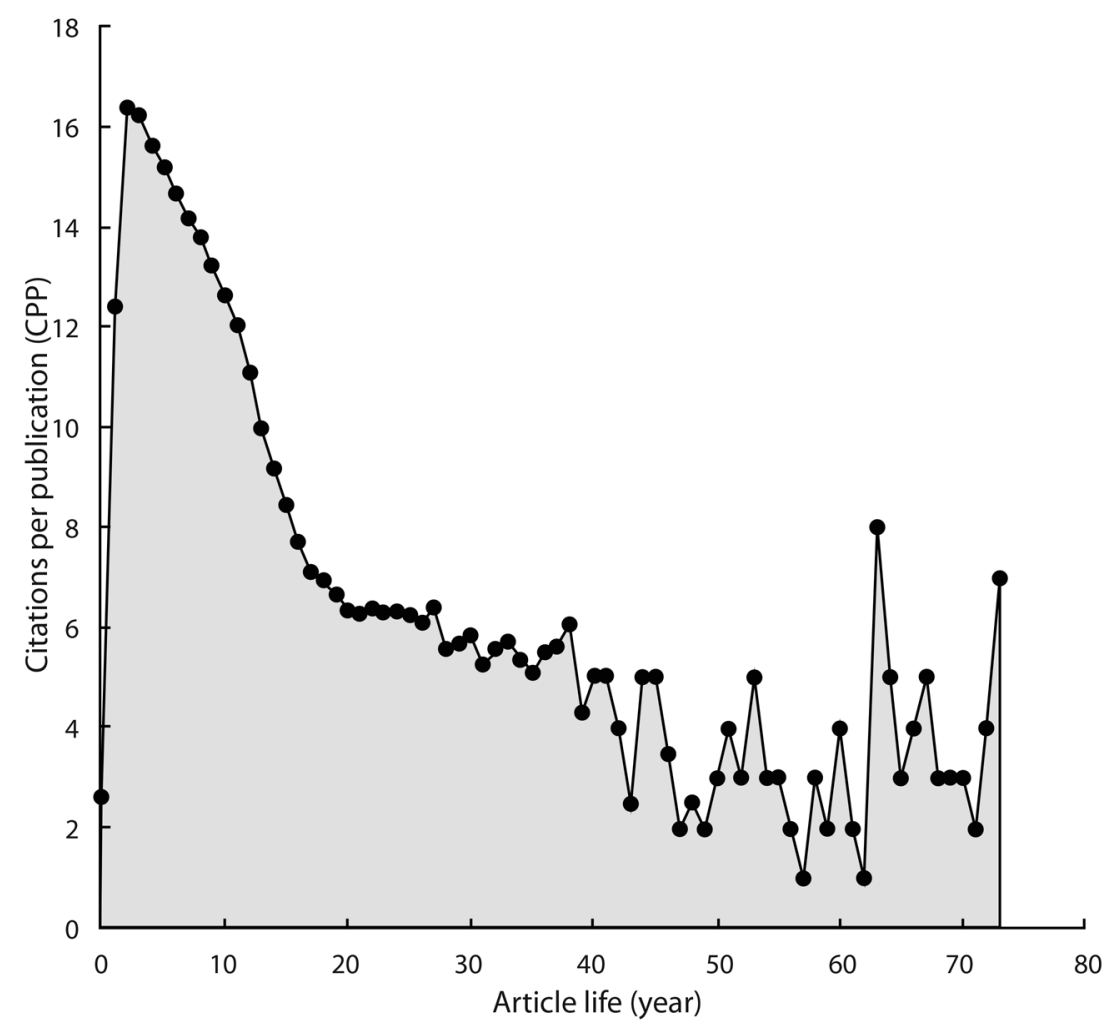

Fig. 1. Proportion of Nicaraguan publications of each document type in the Science Citation Index Expanded (total 1107 publications).

All tropical medicine articles appeared in only 19 journals and the most cited $\left(T C_{2014}=135\right)$ was "Clinical, epidemiologic, and virologic features of dengue in the 1998 epidemic in Nicaragua" (Harris et al., 2000). It was published by 16 authors from the University of California (Berkeley, USA) and three institutes in Nicaragua, in American Journal of Tropical Medicine and Hygiene (and listed in two categories: Public, environmental and occupational health; and Tropical medicine).

In total, 837 Nicaraguan articles were published in 456 journals. Most were published in American Journal of Tropical Medicine and Hygiene with $I F_{2014}$ of 2.699 (21 articles; 2.5 $\%$ of 837 articles), followed by PLoS Neglected Tropical Diseases with $I F_{2014}$ of 4.446 (19; $2.3 \%$ ), Journal of Clinical Microbiology with $I_{2014}$ of $3.993(14 ; 1.7 \%)$, Revista de Biología
Tropical with $I F_{2014}$ of 0.524 (13; $1.6 \%$ ), Pediatric Infectious Disease Journal with $I F_{2014}$ of $2.732(11 ; 1.3 \%)$, PLoS One with $I F_{2014}$ of $3.234(11 ; 1.3 \%)$, and International Journal of Occupational and Environmental Health with $I F_{2014}$ of $1.365(10 ; 1.2 \%)$.

International collaborations: International collaboration articles accounted for 92 $\%$ of Nicaraguan output (Table 1) and resulted from cooperation with 94 countries. This suggests a lack of internal capacity to produce publications included in the SCIEXPANDED; a possibility that is supported by the fact that Nicaraguan researchers are almost never the main authors of the papers (Table 2).

Nicaraguan researchers publish most collaborative work (37\%) with the USA and Sweden $(180 ; 22 \%)$. Regional collaboration is done 


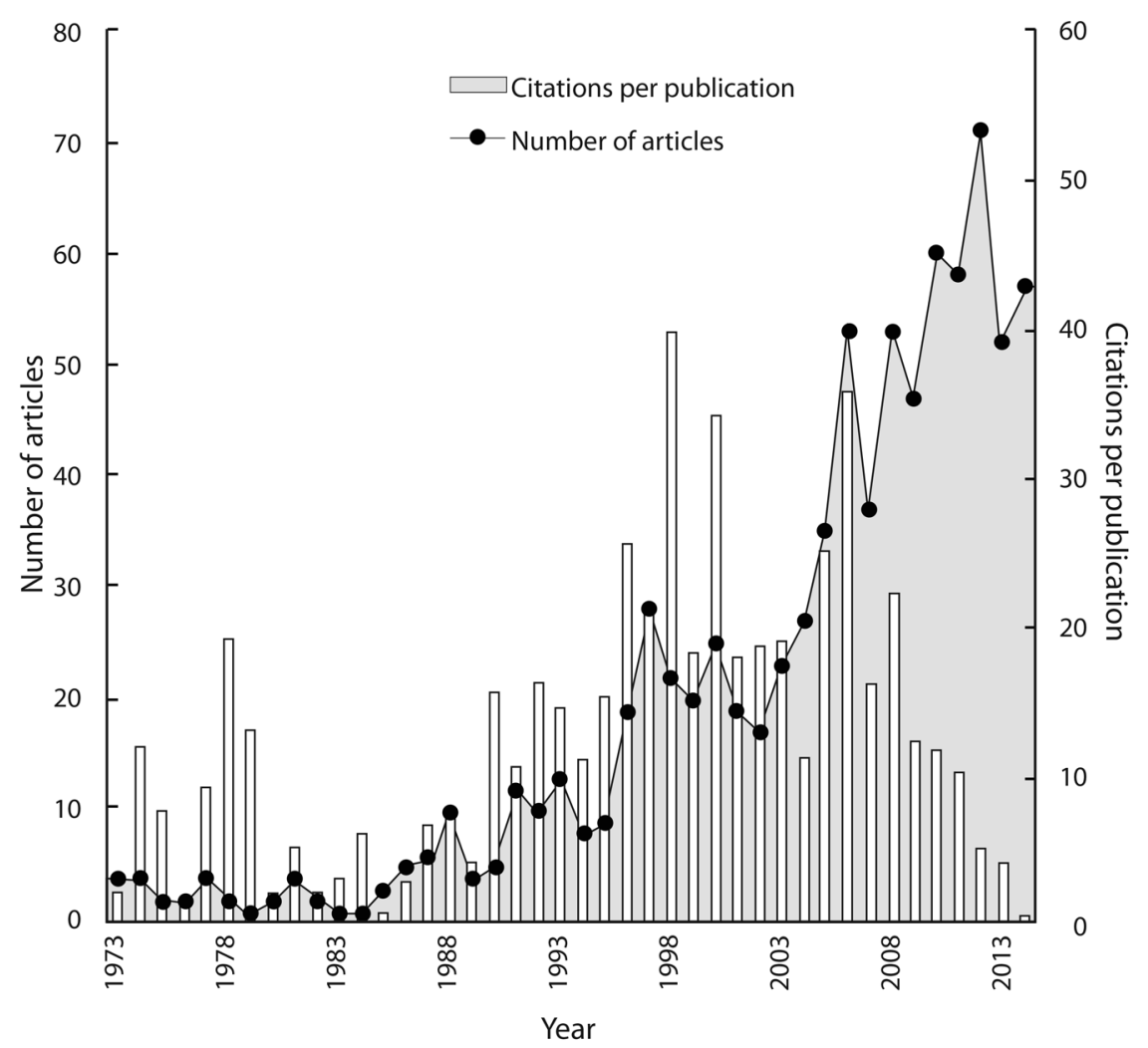

Fig. 2. Number of journals and percentage per subject.

with the most productive countries to the South and North of Nicaragua, such as Costa Rica (92; $11 \%$ ) and Mexico (75; $9.0 \%)$. The rest is done with other Spanish-speaking countries, Brazil (where a similar language is spoken) and with the main European producers of scientific literature (Table 1). Furthermore, the top five internationally collaborative institutions were the University of California, Berkeley in USA with 55 internationally collaborative articles (6.6\% of 873 articles) with Nicaragua, followed by the Karolinska Institutet ( 35 articles; $4.2 \%$ ) and Swedish University of Agricultural Sciences $(35 ; 4.2 \%)$ in Sweden, National University of Costa Rica (27; $3.2 \%)$, and National Autonomous University of Mexico (25; $3.0 \%$ ).

The article "Oral ketoconazole in the treatment of Leishmaniasis" (Urcuyo \& Zaias, 1982) from Instituto Nicaragüense de Dermatología was the most frequently cited Nicaraguan independent article with a $T C_{2014}$ of 79 .
National institutional collaborations: Of 837 exclusively Nicaraguan articles, only $1.1 \%$ were national collaborations, which indicates a tendency not to publish with other local researchers.

Top institutions: The most productive institutions are the Universidad Nacional Autónoma de Nicaragua-Managua (UNAN), and the similarly named Universidad Nacional Autónoma de Nicaragua-León (UNAN), which despite the names actually are different institutions since their separation in 1982; as well as the Ministerio de Salud (Health Ministry) (Table 2). UNAN-Managua published $26 \%$ of the 873 Nicaraguan articles in the database. Except for five articles (7.1\% of 71 Nicaragua independent articles), the UNAN ranked top one in indicators such as total number of Nicaraguan articles (26\% of 837 articles); internationally collaborative articles $(27 \%)$; 
TABLE 1

Top 17 collaborative countries for Nicaragua articles in the Science Citation Index Expanded (1973-2014, only countries with more than 30 articles)

\begin{tabular}{lcccc}
\multicolumn{1}{c}{ Country } & CP & CPR (\%) & FPR $(\%)$ & RPR (\%) \\
USA & 308 & $1(37)$ & $1(26)$ & $1(28)$ \\
Sweden & 180 & $2(22)$ & $2(13)$ & $2(13)$ \\
Costa Rica & 92 & $3(11)$ & $8(1.9)$ & $8(1.9)$ \\
Mexico & 75 & $4(9.0)$ & $4(3.2)$ & $4(3.9)$ \\
Spain & 68 & $5(8.1)$ & $3(5.6)$ & $3(5.7)$ \\
UK & 53 & $6(6.3)$ & $6(2.6)$ & $6(2.6)$ \\
Colombia & 48 & $7(5.7)$ & $20(0.60)$ & $17(0.77)$ \\
Honduras & 43 & $8(5.1)$ & $29(0.12)$ & $25(0.26)$ \\
El Salvador & 38 & $9(4.5)$ & $29(0.12)$ & N/A \\
France & 37 & $10(4.4)$ & $7(2.2)$ & $7(2.2)$ \\
Germany & 37 & $10(4.4)$ & $5(2.9)$ & $5(3.2)$ \\
Brazil & 34 & $12(4.1)$ & $16(0.84)$ & $15(0.90)$ \\
Canada & 32 & $13(3.8)$ & $13(1.3)$ & $11(1.4)$ \\
Cuba & 32 & $13(3.8)$ & $17(0.72)$ & $17(0.77)$ \\
Guatemala & 31 & $15(3.7)$ & $29(0.12)$ & N/A \\
Switzerland & 31 & $15(3.7)$ & $11(1.6)$ & $10(1.5)$ \\
Italy & 30 & $17(3.6)$ & $8(1.9)$ & $11(1.4)$ \\
\hline
\end{tabular}

$C P$ : internationally collaborative articles with Nicaragua; $C P R(\%)$ : rank of internationally collaborative articles and percentage; FPR (\%): rank of article with first author and percentage; $R P R(\%)$ : rank of article with corresponding author and percentage.

TABLE 2

Top 10 institutions for Nicaragua articles in the Science Citation Index Expanded

\begin{tabular}{lccccccc}
\multicolumn{1}{c}{ Institute } & TP & TPR (\%) & $\%$ IC (IC) & $\%$ NC (NC) & $\%$ II (II) & $\%$ FP (FP) & $\%$ RP (RP) \\
Universidad Nacional Autónoma de Nicaragua & 219 & $1(26)$ & $95(209)$ & $0.46(1)$ & $4.1(9)$ & $20(43)$ & $16(35)$ \\
Ministerio de Salud de Nicaragua & 92 & $2(11)$ & $99(91)$ & $1.1(1)$ & $0(0)$ & $5.4(5)$ & $4.3(4)$ \\
Universidad Nacional Autónoma de Nicaragua, León & 72 & $3(8.6)$ & $94(68)$ & $0(0)$ & $5.6(4)$ & $29(21)$ & $25(18)$ \\
Universidad Nacional Agraria de Nicaragua & 55 & $4(6.6)$ & $91(50)$ & $0(0)$ & $9.1(5)$ & $25(14)$ & $24(13)$ \\
Universidad Centroamericana, Managua & 40 & $5(4.8)$ & $75(30)$ & $7.5(3)$ & $18(7)$ & $33(13)$ & $28(11)$ \\
Instituto Nicaragüense de Estudios Territoriales & 32 & $6(3.8)$ & $100(32)$ & $0(0)$ & $0(0)$ & $3.1(1)$ & $3.1(1)$ \\
Universidad Nacional de Ingeniería & 26 & $7(3.1)$ & $100(26)$ & $0(0)$ & $0(0)$ & $23(6)$ & $23(6)$ \\
Hospital Infantil Manuel de Jesús Rivera & 21 & $8(2.5)$ & $100(21)$ & $0(0)$ & $0(0)$ & $4.8(1)$ & $4.8(1)$ \\
Instituto de Ciencias Sostenibles & 19 & $9(2.3)$ & $100(19)$ & $0(0)$ & $0(0)$ & $16(3)$ & $16(3)$ \\
Centro Nacional de Diagnóstico y Referencia & 12 & $10(1.4)$ & $100(12)$ & $0(0)$ & $0(0)$ & $0(0)$ & $0(0)$ \\
\hline
\end{tabular}

$T P$ : total number of articles; TPR (\%): rank of total number of articles and percentage; \% IC (IC): percentage in $T P$ in an institute and number of internationally collaborative articles; \% $N C(N C)$ : percentage in $T P$ in an institute and nationally collaborative articles; \% II (II): percentage in TP in an institute and institutional independent articles; \% FP $(F P)$ : percentage in $T P$ in an institute and first author articles; $\% R P(R P)$ : percentage in $T P$ in an institute and corresponding author articles. 
first author articles (5.1\%); corresponding author articles $(4.5 \%)$; institutional independent articles (15\%); and single author articles (13\%). On the other hand, the UNAN had no nationally collaborative articles.

The top institutions are also the oldest: UNAN León, founded in 1680, is among the oldest universities in the American continent; UNA (National Agriculture School) was founded in 1917; UNI (National Engineering School) in 1941; and UCA (Central American University), run by Jesuits with scientific inclination and founded in 1960, was the first private university in Central America. The only "young" institutions among the top producers are the INET (National Institute for Territorial Studies), founded in 1981 to produce geographic data for development and environmental emergencies; and the Manuel de Jesús Rivera Children's Hospital, founded in 1982, which is a well financed institution that works in close association with European research centers such as the Karolinska Institutet and the University of Milan.

If institutions in Table 2 are labeled as large, medium and small by their productivity, UNAN-Managua is alone in the top category, i.e. it is by far the most important Nicaraguan institution from the point of view of presence in this database (Table 2). The Ministry of Health, UNAN-León and Universidad Agraria are mid level institutions, and the rest have comparatively low productivity.

\section{Authors' performances and article time} trends: The authors with more publications in the database were A. Balmaseda, R. Peña, W. Strauch, and F. Bucardo (Table 3). Ángel Balmaseda works with the Nicaraguan Health Ministry in the specialty of viruses (dengue, influenza, HIV) and publishes as part of international teams from the USA, Brazil and Thailand. Rodolfo Peña and Filemón Bucardo, from Universidad Nacional Autónoma de Nicaragua, León, study -among others- viral, gastrointestinal and pregnancy-related diseases, also as part of international teams often related with the University of Uppsala (Sweden).

By subject, the top Nicaragua independent articles by citations dealt with health problems, forest tenure and food production (Table 4).

The article lifespan is surprisingly long, over 70 years (Fig. 3).

TABLE 3

Top 14 authors for Nicaragua articles in the Science Citation Index Expanded. Only authors with at least 10 articles

\begin{tabular}{llccc}
\multicolumn{1}{c}{ Author } & \multicolumn{1}{c}{ Affiliation } & $T P(\%)$ & $F P(\%)$ & $R P(\%)$ \\
A. Balmaseda & Ministerio de Salud de Nicaragua & $46(5.5)$ & $7(0.84)$ & $1(0.13)$ \\
R. Peña & Universidad Nacional Autónoma de Nicaragua, León & $22(2.6)$ & $3(0.36)$ & $3(0.39)$ \\
W. Strauch & N/A & $22(2.6)$ & N/A & N/A \\
F. Bucardo & Universidad Nacional Autónoma de Nicaragua, León & $18(2.2)$ & $8(0.96)$ & $1(0.13)$ \\
A. Aragón & Universidad Nacional Autónoma de Nicaragua, León & $14(1.7)$ & $2(0.24)$ & $2(0.26)$ \\
S. Vílchez & Universidad Nacional Autónoma de Nicaragua & $14(1.7)$ & $3(0.36)$ & $1(0.13)$ \\
A. C. Gorter & Instituto Centroamericano de la Salud & $12(1.4)$ & $4(0.48)$ & $2(0.26)$ \\
J. K. McCrary & Fundación Gaia & $12(1.4)$ & $7(0.84)$ & $7(0.9)$ \\
Y. Tellez & N/A & $12(1.4)$ & N/A & N/A \\
F. Báez & Hospital Infantil Manuel de Jesús Rivera & $11(1.3)$ & $3(0.36)$ & $1(0.13)$ \\
A. González & N/A & $11(1.3)$ & N/A & N/A \\
E. Valladares & Hospital Escuela Oscar Danilo Rosales Argüello & $11(1.3)$ & $3(0.36)$ & $3(0.39)$ \\
J. C. Mercado & N/A & $10(1.2)$ & N/A & N/A \\
S. Saborío & N/A & $10(1.2)$ & N/A & N/A \\
\hline
\end{tabular}

$T P$ : total number of articles and percentage; $F P R(\%)$ : number of article with first author and percentage; $R P R(\%)$ : number of article with corresponding author and percentage.

N/A: not available. 
The time pattern in the number of articles versus citation showed that articles published less than seven years ago have not yet accumulated a large number of citations (Fig. 4).

In the range of articles with mainly foreign authorships to those with dominance of Nicaraguan authors, it is clear that articles led by foreign authors receive more citations in the SCI-EXPANDED (Fig. 5).

For the most cited authors, citation constantly increased during the first decade, reach a maximum about 12 years after publication, and then start to decrease as the information becomes older (Fig. 6).
For the top five collaborative countries (USA, Sweden Costa Rica, Mexico, and Spain) the number of articles in the database grows during the 1990's and peaks in recent years, suggesting that growth will continue in the near future (Fig. 7).

Details of publications, Impact Factor, references cited and top cited articles appear in Digital Appendices 1-3.

\section{DISCUSSION}

Previous research has found that articles represent the greatest proportion of Latin

TABLE 4

Top 11 Nicaragua independent articles with more than ten citations to 2014

\begin{tabular}{|c|c|c|c|c|}
\hline $\operatorname{Rank}\left(T C_{2014}\right)$ & $\operatorname{Rank}\left(C_{2014}\right)$ & Article title & Institution & Reference \\
\hline $20(79)$ & $444(0)$ & $\begin{array}{l}\text { Oral ketoconazole in the treatment of } \\
\text { Leishmaniasis }\end{array}$ & $\begin{array}{l}\text { Instituto de Dermatología, } \\
\text { Cosmetología y Alergia en } \\
\text { Managua }\end{array}$ & Urcuyo \& Zaias (1982) \\
\hline $64(42)$ & $16(16)$ & $\begin{array}{l}\text { Forest tenure reform in the age of climate } \\
\text { change: Lessons for REDD }+\end{array}$ & $\begin{array}{l}\text { Center for International } \\
\text { Forestry Research }\end{array}$ & Larson (2011) \\
\hline $64(42)$ & $202(2)$ & $\begin{array}{l}\text { Chemical composition and effect of } \\
\text { heat on organic matter- and nitrogen- } \\
\text { degradability and some antinutritional } \\
\text { components of Jatropha meal }\end{array}$ & $\begin{array}{l}\text { Universidad Nacional de } \\
\text { Ingeniería }\end{array}$ & Aderibigbe et al. (1997) \\
\hline $88(35)$ & $202(2)$ & $\begin{array}{l}\text { Natural-history of bairds tapir on Barro } \\
\text { Colorado island, Panama canal zone }\end{array}$ & $\begin{array}{l}\text { Banco Central de } \\
\text { Nicaragua }\end{array}$ & Terwilliger (1978) \\
\hline $172(20)$ & $290(1)$ & $\begin{array}{l}\text { Physiological and biochemical studies } \\
\text { of olive. 1. Variations in concentration } \\
\text { of different metabolites during its } \\
\text { development cycle }\end{array}$ & $\begin{array}{l}\text { Consejo Superior } \\
\text { de Investigaciones } \\
\text { Científicas }\end{array}$ & Donaire et al. (1977) \\
\hline $181(19)$ & $290(1)$ & $\begin{array}{l}\text { The impact of training in integrated pest } \\
\text { management among Nicaraguan maize } \\
\text { farmers: Increased net returns and reduced } \\
\text { health risk }\end{array}$ & $\begin{array}{l}\text { Federación Red Nicasalud } \\
\text { CARE Nicaragua }\end{array}$ & Hruska \& Corriols (2002) \\
\hline $193(18)$ & $290(1)$ & $\begin{array}{l}\text { Lipid effects, effectiveness and } \\
\text { acceptability of tibolone versus } \\
\text { transdermic } 17 \text { beta-estradiol for hormonal } \\
\text { replacement therapy in women with } \\
\text { surgical menopause }\end{array}$ & $\begin{array}{l}\text { Hospital Universitario } \\
\text { Virgen de las Nieves }\end{array}$ & Mendoza et al. (2000) \\
\hline $213(16)$ & $444(0)$ & $\begin{array}{l}\text { Prevalence and characteristics of severe } \\
\text { rotavirus infections in Nicaraguan children }\end{array}$ & $\begin{array}{l}\text { Universidad Nacional } \\
\text { Autónoma de Managua }\end{array}$ & Espinoza et al. (1997) \\
\hline $293(11)$ & $444(0)$ & $\begin{array}{l}\text { Total arsenic in water, fish, and sediments } \\
\text { from Lake Xolotlan, Managua, Nicaragua }\end{array}$ & $\begin{array}{l}\text { Research Center for } \\
\text { Aquatic Resources, } \\
\text { Nicaragua }\end{array}$ & Lacayo et al. (1992) \\
\hline $293(11)$ & $290(1)$ & Nicaragua revolution in pesticide policy & $\begin{array}{l}\text { Universidad Nacional } \\
\text { Autónoma de Managua }\end{array}$ & Swezey et al. (1986) \\
\hline
\end{tabular}

$T C_{2014}$ : total number of times article cited from the Web of Science Core Collection since its publication to the end of 2014: $C_{2014}$ : total number of citations of a paper in 2014 only. 


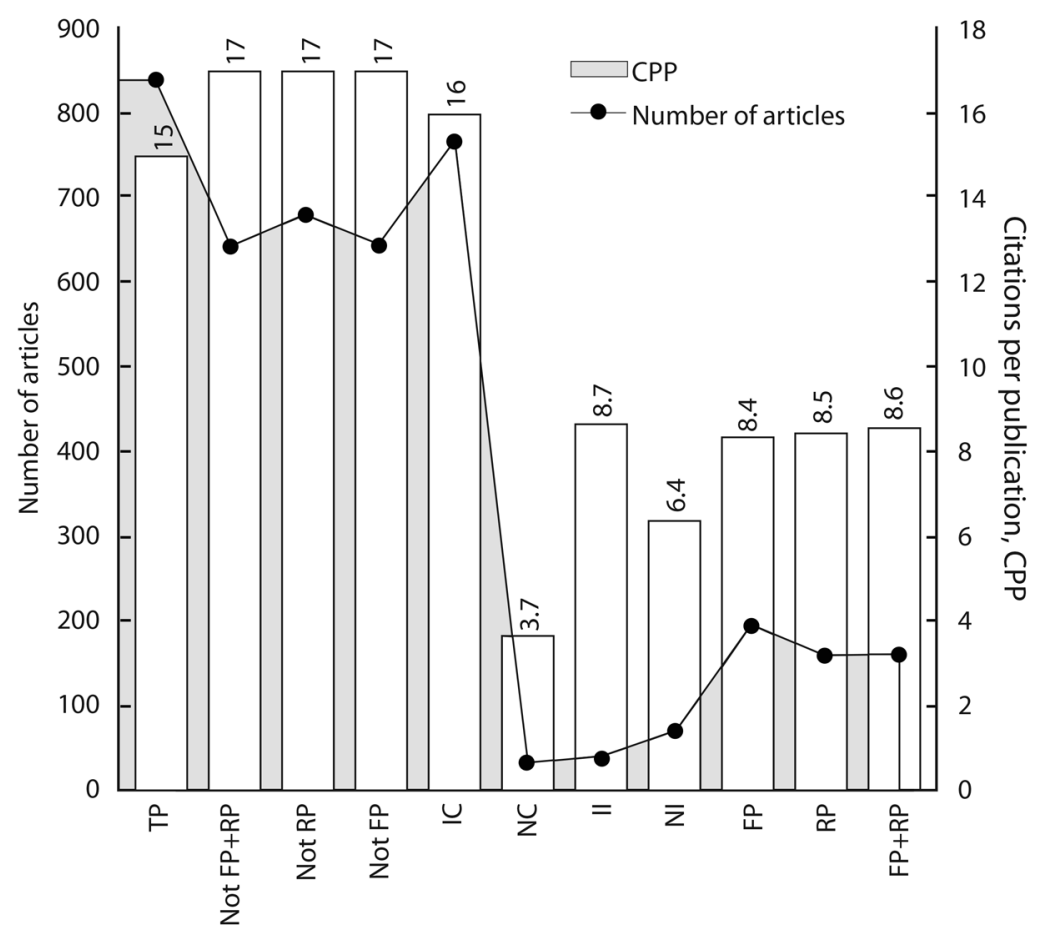

Fig. 3. Article lifespan for Nicaraguan publications.

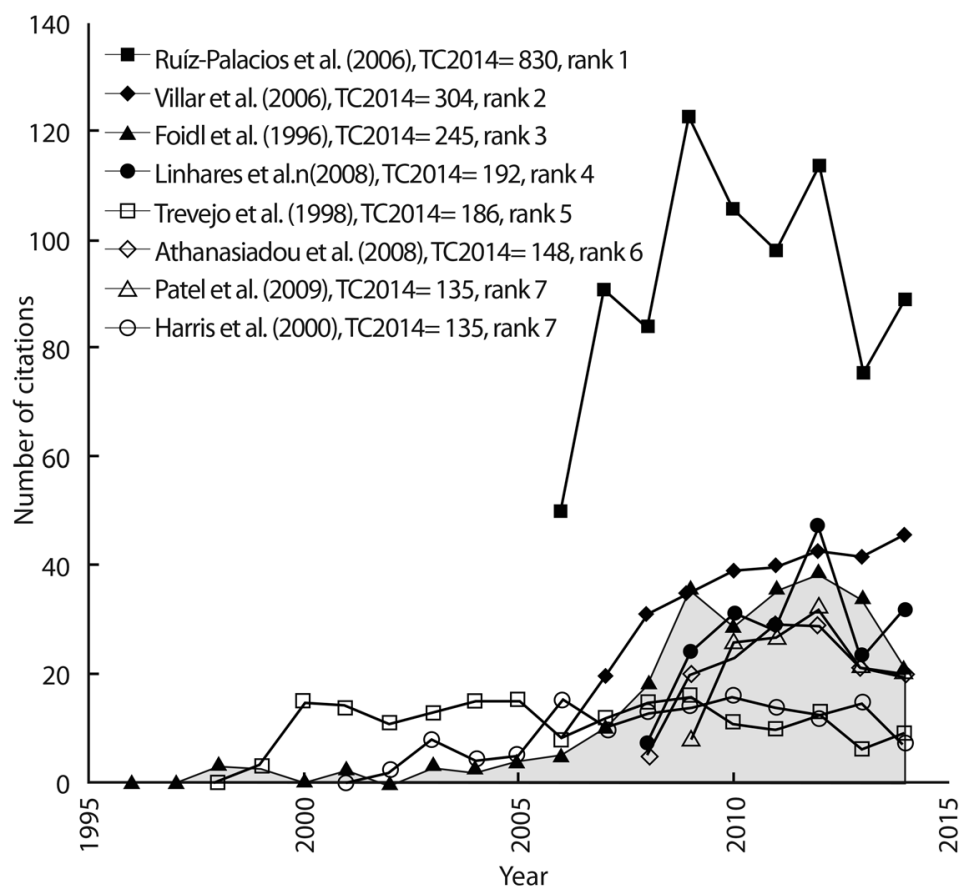

Fig. 4. Citations per publication (in the SCIEXPANDED only) versus number of articles per year. 


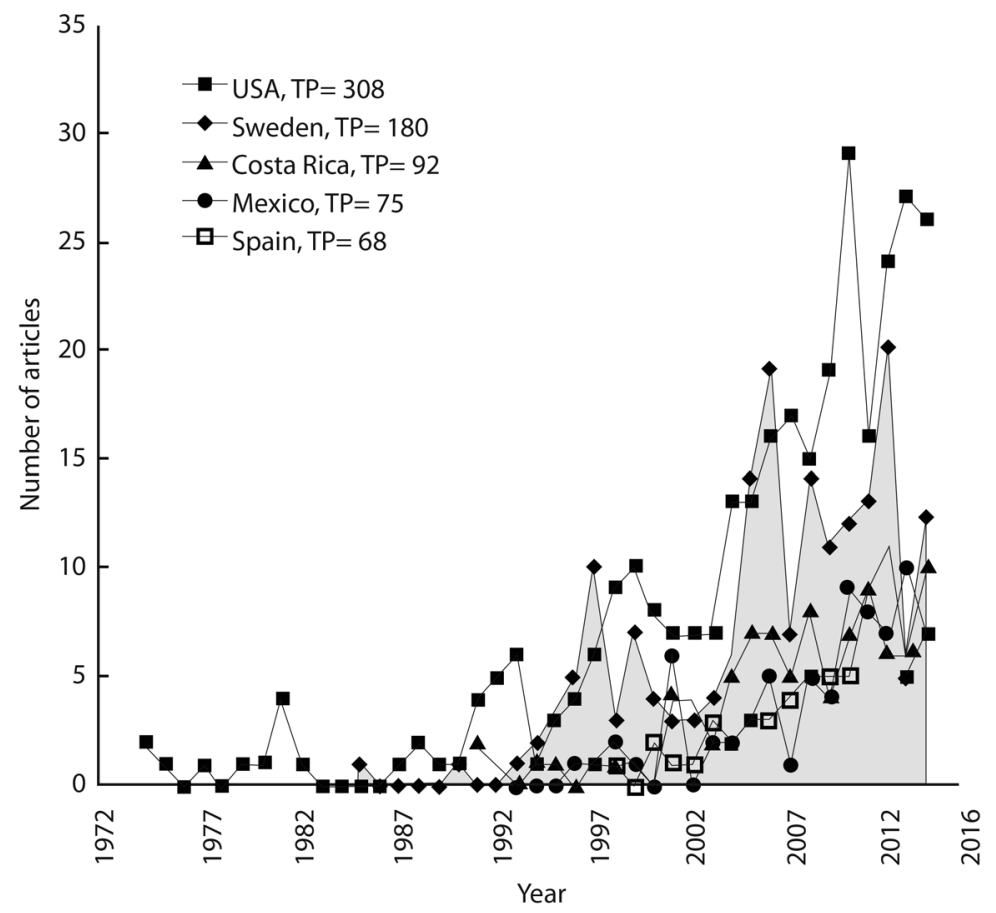

Fig. 5. Citations per publication (in the SCIEXPANDED only) versus authorship and collaboration. TP: total articles. Not FP+RP: both first and corresponding authors are not from Nicaragua. Not RP: corresponding author is not from Nicaragua. Not FP: first author is not from Nicaragua. IC: internationally collaborative papers. NC: nationally collaborative papers. II: institutional independent papers. NI: Nicaragua independent papers. FP: first author is from Nicaragua. RP: corresponding author is from Nicaragua. FP+RP: both first and corresponding authors are from Nicaragua.

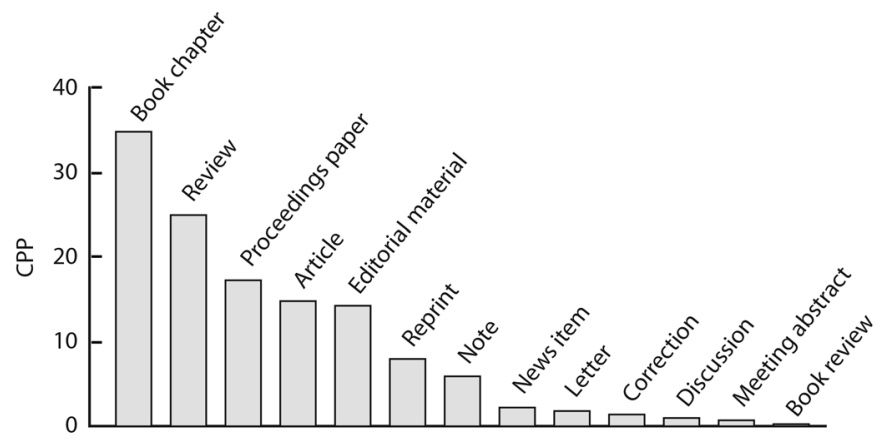

Fig. 6. Citations per publication (in the SCIEXPANDED only) versus year for the most cited authors.

American presence and accumulate the most citations in the SCIEXPANDED (NielsenMuñoz, Azofeifa-Mora, \& Monge-Nájera, 2012; Monge-Nájera \& Ho, 2015). The Nicaraguan case is atypical because a book chapter appears among the most cited publications and because health research represents most of the publications, in contrast with neighboring countries like Costa Rica and Panama, where there is a better representation of other research areas (Nielsen-Muñoz et al., 2012; MongeNájera \& Ho, 2015). Additional research 


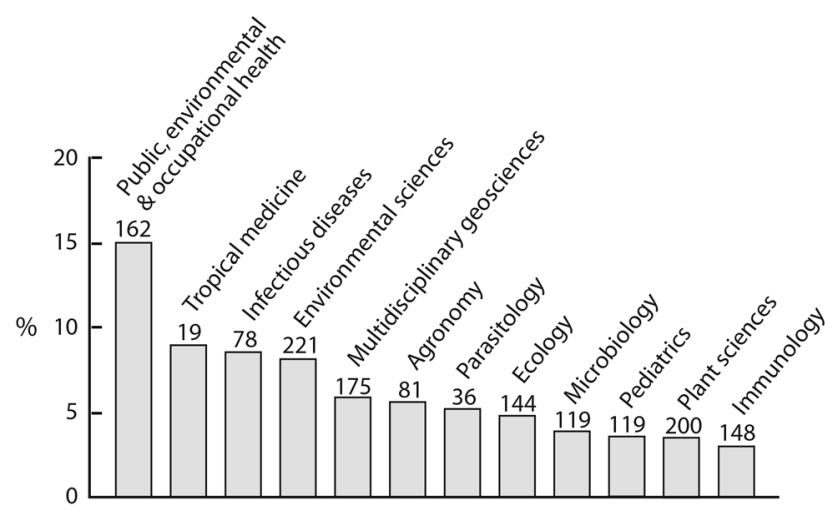

Fig. 7. Number of articles per country for top collaboration countries.

is recommended to find out why Nicaragua is different from other Latin American countries.

The predominance of English publications may reflect a bias of the database itself. Probably most of the scientific production of Nicaraguan scientists is published in Spanish in the many journals published locally (MongeNájera, 2002; list in latindex.unam.mx). The SCIEXPANDED does not include those journals and thus misses both much of the Nicaraguan scientific production and most of its citations (this is a problem affecting all tropical countries: Monge-Nájera, 2014; Monge-Nájera \& Ho, 2015). In other words, the Science Citation Index cannot be used alone to assess the real impact of Nicaraguan publications in world science.

The importance of Sweden in international collaboration can be explained by scholarships that allow Nicaraguans to study microbiology in the Karolinska Institutet. To obtain their degrees there, Nicaraguan students must publish several articles in leading international journals. This mechanism gives Nicaraguan researchers first class laboratories, good financing, tutoring, and access to leading journals for as long as they stay in Sweden (B. Morera, personal communication, 2016). Collaboration with institutions in tropical countries, in turn, allows the Karolinska Institutet to produce over $40 \%$ of all medical research in Sweden (ki.se/en/startpage).
Three of our results indicate that Nicaragua lacks a strong scientific community: little of its research and citation is based on independent local work; most work is about solving urgent practical problems; and women are rare among its most productive and cited researchers. This conclusion from our data was also reached by the Nicaraguan scientists themselves: they have publicly complained that science is ignored by the Nicaraguan government and that Nicaragua is at the bottom of the research investment rank in the American continent (CEPAL, 2010; Massarini, 2011).

A continuous lack of funds and infrastructure can lead some scientists to participate in the "Samples for Coauthorship" system described more than a decade ago by Mata (2002). The system is based on local researchers providing samples and materials to teams based on rich institutions, in exchange for co-authorship in articles published in large journals to which only well funded researchers have access. If not based on equality, that practice can become unethical if the researcher from a small institution - usually located in a tropical country- acts as little more than a field collector (Mata, 2002; Huete, 2008). We ignore if this system could be operating in some Nicaraguan institutions, but it is, nevertheless, better than no research at all because it generates information about local problems and gives local researchers an idea of how science operates in developed countries (Monge-Nájera, 2002). 
Nicaraguan research centers lack appropriate infrastructure, as well as human and financial resources, have inadequate recruiting processes and underpay their scientists (CEPAL, 2010). Our results about the scientific output of Nicaragua, as represented in the SCIEXPANDED, corroborate those findings from five years ago and indicate that the situation has not improved. Future achievements for Nicaraguan science should include a fair presence of female researchers, peer-to-peer level participation in international teams, and development of innovative science, instead of the current extreme focus on health technologies.

\section{ACKNOWLEDGMENTS}

We thank two anonymous reviewers for their suggestions.

\section{RESUMEN}

Bibliometría de las publicaciones de Nicaragua en el Science Citation Index Expanded. Nicaragua es un pequeño país centroamericano, sobre cuya producción científica se ha publicado poco. La mayoría de las publicaciones disponibles en bases de datos internacionales tratan sobre temas de salud y provienen de la Universidad Nacional Autónoma de Nicaragua (Managua), que participa en equipos internacionales. En este artículo analizamos con mayor profundidad $-\mathrm{y}$ por un período más largo que cualquier estudio previo- las publicaciones científicas de Nicaragua hasta enero 2016. En total, aparecieron 837 en 456 revistas del SCIEXPANDED, siento American Journal of Tropical Medicine and Hygiene la principal revista. Un $92 \%$ fueron en colaboración con 94 países, mientras que sólo el $8.5 \%$ fue producción independiente de Nicaragua. El más citado en esa base de datos fue un artículo sobre el uso de ketoconazol para el tratamiento de la leishmaniasis. Los autores con mayor número de publicaciones en la base de datos fueron A. Balmaseda, R. Peña, W. Strauch y F. Bucardo. Los principales artículos exclusivamente nicaragüenses tratan problemas de salud, tenencia de los bosques y producción de alimentos. La "vida en citas" de los artículos es sorprendentemente prolongada, pues son citados hasta por 70 años a partir de su publicación. La mayoría de las citas comienzan siete años después de la publicación, por lo que no son contabilizadas por el SCIEXPANDED, que por tal motivo no es un indicador válido del impacto de los artículos nicaragüenses. El predominio de las publicaciones en inglés puede reflejar un sesgo de la propia base de datos: probablemente la mayor parte de la producción de los científicos nicaragüenses se publica en español en las muchas revistas locales y no se incluye en SCIEXPANDED. Los centros de investigación nicaragüenses carecen de infraestructura adecuada, así como de recursos humanos y financieros necesarios. Los futuros logros de la ciencia en Nicaragua deben incluir una presencia equitativa de mujeres, la participación igualitaria en equipos internacionales y un menor sesgo hacia las tecnologías sanitarias.

Palabras clave: Nicaragua, SCI-EXPANDED, Web of Science, tendencias de investigación.

\section{REFERENCES}

Aguado, E. \& Rogel, R. (2006). Redalyc: Red de Revistas Científicas de América Latina, el Caribe, España y Portugal. Un balance a tres años de camino. Buenos Aires: CLACSO, Consejo Latinoamericano de Ciencias Sociales, 209-233. Retrieved from http:// bibliotecavirtual.clacso.org.ar/ar/libros/secret/babini/ Aguado\%20Lopez\%20Salazar.pdf

Aguillo, I., Ortega, J., Prieto, J., \& Granadino, B. (2007). Indicadores Web de actividad científica formal e informal en Latinoamérica. Revista Española de Documentación Científica, 30(1), 49-60. doi: 10.3989/redc.2007.v30.i1.368

Arencibia, R., Araujo, J. A., Hung L., Alemán-Zeledón, F. S., Chinchilla-Rodríguez, Z., Hernández-Cañadas, P., \& de Moya-Anegón, F. (2011). Bibliometric study of Latin American countries supported by INASP 1996-2008. Oxford: INASP. Retrieved from http:// goo.g1/B9yk7r

Cañedo, A .R. (2009). Cuba, Iberoamérica y la producción científica en salud en la base de datos PubMed en el período 1999-2008. ACIMED, 20(1), 1-27.

Cañedo, R., Hernández, A., \& Fresno, C. (2003). Iberoamérica a 500 años del descubrimiento: la producción científica de una región en ciencias biomédicas en la década de los ochenta. ACIMED, 11(1), 7-8.

Comisión Económica para América Latina y el Caribe (CEPAL). (2010). Plan Nacional de Ciencia, Tecnología e Innovación, Nicaragua 2010-2013. Santiago, Chile: Comisión Económica para América Latina y el Caribe, CEPAL: Documentos de Proyectos, Estudios e Investigaciones. Retrieved from http://goo.gl/CvubdD

Flores, A. M., Penkova, S., \& Román, A. (2009). Once años de LATINDEX: Una experiencia al servicio de las publicaciones científicas Iberoamericanas. Simbiosis, 6(1), 1548-3436.

Fu, H. Z., Long, X., \& Ho, Y. S. (2014), China's research in chemical engineering journals in Science Citation Index Expanded: A bibliometric analysis. Scientometrics, 98(1), 119-136.

Gantman, E. R. (2008). La eficiencia relativa de los países de América Latina en la producción de conocimiento 
científico: una aproximación empírica mediante data envelope analysis. XIV Jornadas de Epistemología de las Ciencias Económicas. Facultad de Economía, Universidad de Buenos Aires. Retrieved from http:// goo.gl/PpXfxK

Harris, E., Videa, E., Perez, L., Sandoval, E., Tellez, Y., Perez, M. D., Cuadra, R., (...), \& Balmaseda, A. (2000). Clinical, epidemiologic, and virologic features of dengue in the 1998 epidemic in Nicaragua. American Journal of Tropical Medicine and Hygiene, 63(1-2), 5-11.

Ho, Y. S. (2012). Top-cited articles in chemical engineering in Science Citation Index Expanded: A bibliometric analysis. Chinese Journal of Chemical Engineering, 20(3), 478-488.

Huete, P. J. A. (2008). Nicaragua, en materia científica, ¿solo proveedores de materia prima? Envio, 310. Retrieved from www.envio.org.ni/articulo/3709

Larson, A. M., \& Soto, F. (2008). Decentralization of natural resource governance regimes. Annual Review of Environment and Resources, 33, 213-239.

Massarini, L. (2011). Ciencia es 'ignorada' en Nicaragua, dicen cientificos. London: Science and Development Network. Retrieved from http://goo.gl/PvGsjkXXX

Mata, S. J. (2002). La acrobática académica. Semanario Universidad de Costa Rica, 25 enero:16.

Miguel, S. (2011). Revistas y producción científica de América Latina y el Caribe: su visibilidad en SciELO, RedALyC y SCOPUS. Revista Interamericana de Bibliotecología, 34(2), 187-199.

Monge-Nájera, J. (2002). Cómo hacer ciencia en los trópicos. Revista de Biología Tropical, 50(3-4), XIX-XXVIII.

Monge-Nájera, J. (2014). La invalidez del Factor de Impacto como indicador del impacto de las revistas científicas latinoamericanas. Revista de Biología Tropical, 62(1), 407-412.
Monge-Nájera, J., \& Ho, Y. S. (2015). Bibliometry of Panama publications in the Science Citation Index Expanded: publication type, language, fields, authors and institutions. Revista de Biología Tropical, 63(4), 1255-1266.

Nielsen-Muñoz, V., Azofeifa-Mora, A. B., \& Monge-Nájera, J. (2012). Bibliometry of Costa Rica biodiversity studies published in the Revista de Biología Tropical/ International Journal of Tropical Biology and Conservation (2000-2010): the content and importance of a leading tropical biology journal in its 60th Anniversary. Revista de Biología Tropical, 60(4), 1405-1413.

Picado, A., Munguía, M., \& Rojas, S. (2010). Análisis Bibliométrico de las Publicaciones Científicas de Nicaragua en el Science Citation Index Expanded: Trienio 2007-2009. 1st Latin-American Multidisciplinary Congress of Applied Sciences. National Polytechnic Institute (IPN), México. Retrieved from http://www.diva portal.org/smash/record.jsf?pid=div a2\%3A530091\&dswid $=6982$

Raiher, S. (2010). Estudio comparativo entre la producción cientifica latinoamericana y mundial en inequidades en salud durante los años 1999-2008 (Tesis Licenciatura). Universidad Nacional de La Plata, Argentina. Retrieved from http://www.memoria.fahce.unlp.edu. ar/tesis/te.361/te.361.pdf

Ríos, C. \& Herrero, V. (2005). La producción científica latinoamericana y la ciencia mundial: una revisión bibliográfica (1989-2003). Revista Interamericana de Bibliotecología, 28(1), 43-61.

Santa, S., \& Herrero, V. (2010). Producción científica de América Latina y el Caribe: una aproximación a través de los datos de Scopus (1996 - 2007). Revista Interamericana de Bibliotecología, 33(2), 379-400.

Urcuyo, F. G., \& Zaias, N. (1982). Oral ketoconazole in the treatment of Leishmaniasis. International Journal of Dermatology, 21(7), 414-416.

Wang, M. H., Yu, T. C., \& Ho, Y. S. (2010). A bibliometric analysis of the performance of Water Research. Scientometrics, 84(3), 813-820.

\section{EDITED BY Vanessa Nielsen}


